\title{
PENDAFTARAN ONLINE JAMINAN FIDUSIA SEBAGAI SUATU FASILITAS KREDIT DENGAN POTENSI LEMAHNYA PERLINDUNGAN KREDITOR
}

\author{
Fani Martiawan Kumara Putra \\ Fakultas Hukum Universitas Wijaya Kusuma Surabaya \\ e-mail: fanimartiawan@gmail.com
}

\begin{abstract}
ABSTRAK
Perkembangan Hukum Jaminan, juga membawa perkembangan atas lembaga jaminannya, antara lain lembaga jaminan yang merupakan bentuk perkembangan Hukum Jaminan adalah Fidusia. Fidusia sebagai lembaga jaminan yang cukup diminati, pengaturannya juga dikembangkan demi kemudahan dalam keseluruhan prosesnya, antara lain yaitu dengan diadakannya pendaftaran online untuk lembaga jaminan Fidusia. Pendaftaran online yang tentunya memiliki mekanisme yang berbeda dengan pendaftaran biasa, sudah barang tentu memiliki karakter perlindungan yang berbeda untuk kreditornya. Tentunya saat beranjak dari konsep pendaftaran online, kedudukan kreditor bukannya cenderung membaik, namun berpotensi menjadi rawan. Tujuan dari penelitian ini adalah menemukan cara agar kedudukan baik itu kreditor dan debitor dalam pendaftaran online Fidusia itu tidak menjadi rawan dan sama-sama terlindungi oleh hukum yang baik. tidak Penelitian ini merupakan penelitian normatif. Hasil dari penelitian ini adalah adanya rekomendasi bagi pemerintah, untuk membuat suatu aturan lanjutan terkait pendaftaran jaminan Fidusia yang dilakukan secara online, khususnya mengenai pemenuhan asas spesialitas pada Sertifikat Fidusia.
\end{abstract}

Kata Kunci: Kreditor; Fidusia; Pendaftaran; Online

\begin{abstract}
The development of the Security Law, also brought the development of its security law institution, among others institution which is the form of the development of the Security Law is Fiduciary. Fiduciary as a security institution is quite attractive, the arrangement is also developed for ease in the whole process, such as online registration. Online registration that certainly has a different mechanism with regular registration, it certainly has a different protection character for its creditors. Surely when starting from the concept of online registration, the position of creditors rather than tend to improve, but potentially become prone. The purpose of this study is to find a way for both creditors and debtors who register the Fiduciary online, not to be vulnerable and equally protected by law. This research is a normative study. The result of this research is a recommendation for the government, to make a follow-up regulation related to registration of Fiduciary done online, especially regarding the fulfillment of speciality principle on Fiduciary Certificate.
\end{abstract}

Keywords: Creditor; Fiduciary; Registration; Online

\section{PENDAHULUAN}

Jaminan Fidusia saat ini dapat dikatakan sebagai lembaga jaminan yang paling dibutuhkan dan diminati oleh masyarakat, khususnya atas suatu tindak lanjut kredit kendaraan bermotor. Keadaan ini sebagai akibat dari eksistensi lembaga pembiayaan, dan juga meningkatnya kebutuhan masyarakat akan kredit. Kehadiran lembaga pembiayaan didasari pada tidak sedikitnya kondisi subjek hukum yang membutuhkan barang namun terkendala keuangan, dan ingin memanfaatkan jasa dari subjek hukum 
lain untuk mendapatkan barang tersebut, dengan jalan tidak meminjam uang secara langsung, namun pembelian (pembayaran) atas barang tersebut dilakukan oleh subjek hukum lain, untuk subjek hukum yang memanfaatkan jasanya. Demikian maka sudah dapat dipahami bahwa pembiayaan untuk mendapatkan barang ini berbeda dengan utangpiutang biasa, karena sudah barang tentu bentuk perjanjiannya berbeda, walau pada hakekatnya tetap merupakan suatu kegiatan penyediaan dana.

Pertumbuhan ekonomi sebagai salah satu penunjang perkembangan suatu negara, menuntut perlunya dilakukan beberapa langkah agar unsur pertumbuhan ekonomi yang diharapkan itu berhasil dan sumber dana pembangunan semakin meningkat, salah satunya adalah dengan memperluas sarana penyediaan dana yang dibutuhkan oleh masyarakat, yang artinya peranan lembaga pembiayaan ini perlu untuk terus ditingkatkan secara berkala.

Peningkatan yang dimaksud di atas, juga barang tentu harus didasari pada peningkatan normanya. Dimulai dari Keputusan Presiden Republik Indonesia Nomor 61 Tahun 1988 tentang Lembaga Pembiayaan, kemudian Keputusan Menteri Keuangan Republik Indonesia Nomor 1251/KMK.013/1988 tentang Ketentuan dan Tata Cara Pelaksanaan Lembaga Pembiayaan, kemudian Peraturan Presiden Republik Indonesia Nomor 9 Tahun 2009 tentang Lembaga Pembiayaan, dan terus berkembang hingga saat ini diatur dalam Peraturan Otoritas Jasa Keuangan Nomor 29/POJK.05/2014 tentang Penyelenggaraan Usaha Perusahaan Pembiayaan.

Pada pengaturan mengenai lembaga pembiayaan tersebut, senantiasa ditegaskan bahwa lembaga pembiayaan harus mempunyai keyakinan bahwa konsumen itu dapat melunasi lembaga pembiayaan. Konstruksi hukum seperti ini sudah tentu mengarah pada Hukum Jaminan yang merupakan sarana perlindungan lembaga pembiayaan sebagai pihak kreditor, atas piutangnya. Demi memberikan kepastian kepada lembaga pembiayaan bahwa nanti akan terlunasi, maka lembaga pembiayaan sudah sepatutnya meminta jaminan kepada pengguna jasa yang berkedudukan sebagai debitor. Salah satu obyek yang dapat diberikan oleh debitor sebagai jaminan, adalah benda yang pengadaannya dibiayai oleh lembaga pembiayaan tersebut, bisa jadi kendaraan bermotor atau benda lain. Bermula dari sinilah kemudian dalam prakteknya lembaga pembiayaan itu selalu meminta kendaraan bermotor yang pengadaannya dibiayai olehnya, itu sebagai objek jaminan dari pengguna jasa. Penjaminan kendaraan bermotor sebagai benda bergerak, sudah sepatutnya mengikuti aturan yang ada pada Hukum Jaminan.

Benda bergerak sesuai pengaturan Hukum Jaminan yang awal mulanya ada pada Burgerlijk Wetboek (selanjutnya disingkat BW), dapat dibebankan sebagai objek jaminan dengan menggunakan lembaga jaminan Gadai atau Fidusia, hal ini tergantung pada karakter dan penggunaan benda yang akan dijaminkan tersebut. Perbedaan Gadai dan Fidusia sendiri ada pada penguasaan bendanya, pada lembaga jaminan Gadai, benda yang dijaminkan dikuasai oleh kreditor atau pihak ketiga (inilah asas inbezitstelling yang diatur dalam Pasal 1152 BW), sedangkan pada lembaga jaminan Fidusia benda yang dijaminkan tetap berada dalam kekuasaan debitor (Pasal 1 angka 1 Undang-Undang Nomor 42 Tahun 1999 tentang Jaminan Fidusia).

Manakala benda tersebut merupakan benda bergerak yang dipergunakan untuk keperluan seharihari, khususnya sebagai media utama dalam mencari nafkah, maka benda bergerak yang seperti itu sudah sepantasnya disebut sebagai benda bergerak modal. Sedangkan benda bergerak yang tidak dipergunakan untuk keperluan mencari nafkah sehari-hari, itu sudah sepantasnya disebut sebagai benda bergerak biasa. Benda bergerak biasa, dijaminkan dengan Gadai, hal ini karena Gadai harus memenuhi asas inbezitstelling, sehingga bukan suatu masalah untuk benda bergerak biasa manakala harus dilepaskan dari kuasa debitor. Sedangkan benda bergerak modal dijaminkan dengan lembaga jaminan Fidusia, hal ini karena dalam Fidusia benda yang dijaminkan itu masih dapat dikuasai oleh pihak debitor. Kendati demikian, perlu diingat bahwa meskipun benda itu termasuk benda bergerak modal ataupun benda bergerak biasa, agar dapat dijaminkan, tetap harus memenuhi syarat sebagai objek jaminan, yaitu harus mempunyai nilai ekonomis dan dapat dipindahtangankan.

Sebagai salah satu syarat sah lahirnya jaminan kebendaan, adalah dengan dipenuhinya asas publisitas, asas ini ditujukan untuk mengikat pihak ketiga di luar perjanjian kredit dan jaminan, untuk memberitahukan bahwa benda tersebut sedang dibebani jaminan, dan mengamanahkan agar 
pihak ketiga itu menghormati perjanjian kredit dan jaminan yang sedang membebani benda tersebut. Asas ini berlaku untuk setiap lembaga jaminan di Indonesia, baik itu Gadai, Hipotek, Fidusia, dan Hak Tanggungan.

Pemenuhan asas publisitas untuk lembaga jaminan di Indonesia, dapat dilakukan dengan dua cara, yaitu melalui pendaftaran atau melalui pelepasan benda jaminan dari kuasa pihak debitor. Cara pertama digunakan pada lembaga jaminan Hipotek, Hak Tanggungan, dan Fidusia, sedangkan cara kedua disebut sebagai asas inbezitstelling, dan hanya diterapkan pada lembaga jaminan Gadai (Pasal 1152 BW), hal ini bukanlah merupakan hal yang aneh, karena hanya pada lembaga jaminan Gadai lah objek jaminan itu akan dikuasai oleh pihak kreditor atau pihak ketiga, sedangkan pada Hipotek, Hak Tanggungan dan Fidusia objek jaminan dikuasai oleh debitor, demikian tujuan dari pendaftaran jaminan guna pemenuhan asas publisitas sebagai syarat sahnya, itu adalah untuk lebih melindungi dan memberikan kepastian akan terpenuhinya hak pihak kreditor.

Penggunaan jaminan Fidusia yang kian berkembang jumlahnya, sangat membutuhkan kepraktisan dan kecepatan dalam hal teknis hingga proses penjaminan itu sah. Pengaturan dalam Undang-Undang Nomor 42 Tahun 1999 tentang Jaminan Fidusia (selanjutnya disebut UUJF) pada Pasal 12 ditegaskan bahwa pendaftaran Jaminan Fidusia dilakukan di Kantor Pendaftaran Fidusia. Melalui Peraturan Pemerintah Nomor 21 Tahun 2015 tentang Tata Cara Pendaftaran Jaminan Fidusia dan Biaya Pembuatan Akta Jaminan Fidusia (selanjutnya disebut PP Pendaftaran Fidusia), dengan tujuan peningkatan pelayanan pendaftaran jaminan Fidusia yang mudah dan cepat, maka dibentuk suatu kebijakan baru, yaitu pendaftaran Jaminan Fidusia secara online.

Pendaftaran Jaminan Fidusia secara online ini nantinya juga menghasilkan sertifikat Jaminan Fidusia, yang artinya juga dapat dilaksanakan eksekusi. Pendaftaran online ini tampaknya cukup menjanjikan kemudahan, yang mana atas kemudahan dan kecepatan prosesnya tersebut dalam prakteknya membuat hubungan utang-piutang antara kreditor dan debitor dengan Jaminan Fidusia itu semakin bertambah minatnya.
Kendati memberikan kemudahan, ternyata dalam prakteknya pendaftaran Jaminan Fidusia secara online ini dapat dinilai belum cukup mampu memberikan perlindungan hukum yang baik kepada pihak kreditornya. Hal ini pada pokoknya karena substansi yang tertera pada produk Jaminan Fidusia yang dilahirkan dari pendaftaran secara online, itu membuat kepastian hukumnya layak untuk diragukan.

Sertifikat jaminan Fidusia yang diterbitkan secara online, juga memuat irah-irah sebagai titel eksekutorialnya, dan tanda tangan yang langsung tercetak. Artinya sertifikat jaminan Fidusia ini menambah daftar siapa saja yang berwenang menuliskan irah-irah sebagai titel eksekutorial. Menjadi perlu diperhatikan, siapa sebenarnya pihak yang menuliskan irah-irah dalam sertifikat jaminan Fidusia yang dilakukan online, mengingat tanda tangan yang ada disana juga berbasis digital (scan). Karena semuanya berdasarkan sistem dan data berupa soft copy, maka potensi cela pada data, baik itu hilang atau rusak sudah pasti ada. Kemudian karakter dari sertifikat itu sendiri tidak ada kekhususan yang mengindikasikan keasliannya. Oleh karenanya kedua hal ini dapat dijadikan pintu bagi pihak yang tidak bertanggung jawab untuk membuat sertifikat jaminan Fidusia palsu.

Asas spesialitas pada jaminan Fidusia yang saat ini pendaftarannya dilakukan online, hanya memuat klausula "sesuai akta Notaris", tidak ada salinan atas klausula-klausula yang ada dalam akta Notaris tersebut, bahkan untuk klausula-klausula yang penting guna perlindungan pihak kreditornya. Serupa dengan akta Hipotek yang mana sejatinya klausulaklausula penting guna melindungi kreditor dan juga debitor itu ada dalam Surat Kuasa Memasang Hipotek, namun demikian, guna antisipasi resiko, maka dalam akta Hipotek juga dituliskan beberapa ketentuan yang melindungi pihak kreditor dan debitor, dan yang juga ada dalam Surat Kuasa Memasang Hipotek tersebut. Demikian pemenuhan asas spesialitas dalam Fidusia online ini juga beresiko atas kepastian hukum kedudukan dan perlindungan pihak kreditor dan debitornya.

Masih terdapat beberapa aspek yang tidak tegas dan jelas pengaturannya dalam pendaftaran jaminan Fidusia melalui online, sudah barang tentu hal ini 
Fani Martiawan Kumara Putra,

Pendaftaran Online Jaminan Fidusia Sebagai Suatu Fasilitas Kredit Dengan Potensi Lemahnya Perlindungan Kreditor

membawa implikasi perlindungan hukum bagi kreditornya menjadi layak untuk dipertanyakan.

\section{PERUMUSAN MASALAH}

Berdasarkan latar belakang yang telah diuraikan di atas, maka permasalahan yang akan dibahas dalam penulisan ini adalah mengenai karakteristik perlindungan hukum pihak kreditor yang memanfaatkan kemudahan pendaftaran jaminan Fidusia melalui cara online.

\section{METODE PENELITIAN}

Penelitian ini merupakan penelitian normatif. Metode pendekatan yang digunakan dalam penelitian ini adalah pendekatan perundang-undangan (statute approach).

\section{PEMBAHASAN}

Jaminan pada hakekatnya adalah suatu hal yang disepakati dalam suatu perjanjian dan digunakan untuk memberikan suatu keadaan aman bagi suatu pihak. Jaminan adalah suatu hal karena objek dari jaminan tersebut dapat berupa benda dan dapat pula berupa orang. Pada perihal utang-piutang manakala objek dari jaminan tersebut adalah orang, sudah barang tentu syarat utamanya adalah orang yang dijadikan penanggung tersebut sanggup untuk melunasi utang pihak debitor saat pihak debitor benar-benar dalam keadaan tidak sanggup melakukan pelunasan utangnya. Sedangkan manakala yang dijadikan objek jaminan tersebut adalah suatu benda (dikenal dengan nama jaminan kebendaan), maka sudah barang tentu syarat utamanya adalah benda tersebut harus mempunyai nilai ekonomis dan dapat dipindahtangankan, sebagaimana yang tersirat dalam Pasal 1131 BW.

Tidak dapat dipungkiri bahwa jaminan sebagaimana di atas akan seringkali terjadi sebagai salah satu konsekuensi dari perikatan yang lahir dari perjanjian utang-piutang di masyarakat, oleh karenanya diperlukan pranata hukum yang memuat norma-norma mengenai jaminan ini. Pembuat undang-undang memberikan jalan keluarnya dengan Hukum Jaminan.

Hukum jaminan merupakan pranata hukum yang mengatur mengenai pembebanan jaminan sebagai tindak lanjut dari perjanjian utang-piutang, yang melingkupi pengaturan baik itu jaminan perorangan juga jaminan kebendaan, dengan tujuan untuk memberikan kepastian kepada pihak kreditor akan terlunasi piutangnya, sehingga pihak debitor lebih mudah dalam mendapatkan fasilitas kredit.

Hukum jaminan yang ada pada saat ini di Indonesia, pengaturannya tersebar, mengingat terdapat beberapa lembaga jaminan yang diakui di Indonesia, yang kemudian diatur dalam undangundang tersendiri. Sebagai salah satu cara identifikasi yang paling mudah, hukum jaminan diatur dalam BW dan di luar BW, sedangkan yang diatur dalam BW, diatur dalam Buku II BW dan di luar Buku II BW (ada pada Buku III BW).

Perihal jaminan kebendaan, terdapat 5 (lima) lembaga jaminan kebendaan di Indonesia, namun hanya 4 (empat) yang diakui dalam artian pengaturannya tidak bertentangan dengan prinsip Hukum Jaminan. Lembaga jaminan yang diakui di Indonesia beserta letak pengaturannya adalah:

1. Gadai, diatur melalui Pasal 1150-1160 BW;

2. Fidusia, diatur melalui UUJF;

3. Hak Tanggungan, diatur melalui Undang-Undang Nomor 4 Tahun 1996 tentang Hak Tanggungan; 4. Hipotek, diatur melalui Pasal 1162-1232 BW jo. Undang-Undang Nomor 17 Tahun 2008 tentang Pelayaran jo. Peraturan Menteri Perhubungan No. 39 Tahun 2017 tentang Peraturan dan Pendaftaran Kapal.

Pengaturan yang paling banyak tersebar saat ini, dan tidak ada unifikasi hingga kini, adalah pengaturan lembaga jaminan Hipotek. Sedangkan perihal jaminan perorangan, letak pengaturannya di luar Buku II BW, yaitu pada Buku III BW, yang mana bermula dari Pasal 1820 BW.

Disamping apa yang telah ditegaskan pada Pasal 1 UUJF, disampaikan oleh Munir Fuady bahwa jaminan Fidusia adalah suatu jaminan utang yang bersifat kebendaan (baik utang yang telah ada maaupun utang yang akan ada), yang pada prinsipnya memberikan barang bergerak sebagai jaminannya dengan memberikan penguasaaan dan penikmatan atas benda tersebut kepada debitor (dengan jalan pengalihan hak milik atas benda objek jaminan tersebut kepada kreditor) kemudian pihak kreditor menyerahkan kembali penguasaan dan penikmatan 
atas benda tersebut kepada debitornya secara kepercayaan (Fidusiahary). ${ }^{1}$

Secara eksplisit ditegaskan dalam Pasal 1 UUJF, bahwa Fidusia merupakan suatu hak kebendaan, dalam hal ini sudah barang tentu yang dimaksud oleh pembuat undang-undang adalah hak kebendaan dalam bentuk hak jaminan kebendaan, yang mempunyai sifat-sifat:

1. Absolut (mutlak);

2. Droit de Suite;

3. Droit de Preference;

4. Droit de Priority;

5. Publisitas;

6. Spesialitas;

7. Gugat Kebendaan;

5. Separatis.

Sifat-sifat di atas, telah diakomodir semua dalam

UUJF dan peraturan terkait mengenai Jaminan Fidusia.

Fidusia sebagai jaminan kebendaan sebagai jaminan yang melibatkan benda, mensyaratkan adanya benda khusus yang diikat sebagai jaminan dalam perjanjian utang-piutang. Pengikatan benda sebagai jaminan ini haruslah dengan perjanjian tersendiri, di luar perjanjian utang-piutang. Hal ini karena fungsi dari perjanjian pengikatan jaminan kebendaan itu berbeda dengan perjanjian utangpiutang, perjanjian utang-piutang fungsinya melahirkan hak dan kewajiban terkait pemberian utang dan pembayaran utang, sedangkan perjanjian jaminan fungsinya melahirkan kewajiban si debitor untuk menyerahkan benda yang akan dijaminkan, guna dibebani hak jaminan kebendaan. Perjanjian utang-piutang sifatnya obligatoir, sedangkan perjanjian jaminan tidak. Perjanjian utang-piutang melahirkan perikatan, sedangkan perjanjian jaminan tidak. Inilah pada dasarnya mengapa perjanjian jaminan itu dibuat terpisah dari perjanjian utangpiutang, namun masih dalam satu kesatuan. Terpisah namun masih menjadi satu kesatuan itulah yang membuat perjanjian jaminan disebut perjanjian tambahan (asesoir), dan perjanjian utang-piutang disebut sebagai perjanjian utama (pokok).

Eksistensi perjanjian jaminan sebagai tambahan adalah mengikuti perjanjian pokok, manakala perjanjian pokok hapus, artinya utang-piutang telah

\footnotetext{
${ }^{1}$ Munir Fuady. (2000). Hukum Jaminan Utang. Jakarta: Erlangga, h. 102.
}

selesai, maka sudah barang tentu perjanjian jaminan juga akan ikut hapus pula. Sedangkan manakala perjanjian jaminan hapus, belum tentu perjanjian pokok juga hapus, karena bisa saja perjanjian jaminannya hapus karena objek jaminannya di eksekusi, dan masih menunggu pembayaran untuk melunasi kewajiban pada perjanjian pokok, bisa juga perjanjian jaminannya hapus karena objek jaminannya hilang atau musnah.

Suatu hal yang paling penting, yaitu perjanjian jaminan tersebut tidak akan diakui walaupun telah disepakati oleh kedua belah pihak, manakala perjanjian jaminan tersebut tidak didaftarkan pada tempat yang telah ditunjuk dalam undang-undang. Pendaftaran ini sebagai langkah dalam memenuhi asas publisitas yang menjadi tolak ukur sah atau tidaknya proses pembebanan jaminan. Hal ini menjadi salah satu pembeda antara lembaga jaminan Gadai dan Fidusia.

Pada lembaga jaminan Fidusia, pendaftaran perjanjian jaminan harus melalui tahapan-tahapan yang telah ditentukan dalam UUJF dan peraturan pelaksananya. Sedangkan pada Gadai, sebagaimana amanah Pasal $1151 \mathrm{BW}$, ditegaskan yang mana redaksinya adalah perjanjian jaminan Gadai dibuat oleh para pihak dengan bentuk apapun yang disepakati, sedangkan proses pendaftaran perjanjian jaminan Gadai tidak diperlukan tahapan-tahapan khusus, karena pada hakekatnya pada lembaga jaminan Gadai proses pendaftaran perjanjian jaminan sudah dianggap terlaksana dan terpenuhi tujuan sebenarnya pendaftaran perjanjian jaminan itu, dengan terpenuhinya asas inbezitstelling yang ditegaskan pada Pasal 1152 BW.

Selain itu, pembeda yang lain adalah karakter penguasaan objek jaminannya, dimana pada lembaga jaminan Fidusia itu objek jaminannya dikuasai oleh debitor, sedangkan pada lembaga jaminan Gadai, objek jaminannya dikuasai oleh pihak kreditor (oleh karena itu pembuat undang-undang mempersilahkan para pihak membuat sendiri perjanjian jaminan dengan bentuk yang dikehendaki oleh para pihak).

Pada lembaga jaminan Fidusia, perjanjian jaminan itu dituangkan dalam bentuk Akta Jaminan Fidusia (selanjutnya disingkat AJF) yang kewenangan pembuatannya ada pada Notaris, sebagaimana amanah Pasal 5 UUJF. AJF ini kemudian didaftarkan sebagaimana amanah Pasal 11 UUJF. Demikian 
artinya pada proses penjaminan Fidusia, terdapat berbagai tahapan sebagai berikut:

1. Pembuatan Perjanjian Pokok;

2. Pembuatan Akta Jaminan Fidusia;

3. Pendaftaran Jaminan Fidusia.

Sebagaimana diatur dalam Pasal 14 ayat (3)

UUJF, maka Jaminan Fidusia baru sah lahir saat telah didaftarkan, dan sebagai bukti pendaftaran akan diterbitkan sertifikat. Sertifikat itu mempunyai kekuatan eksekutorial sebagaimana dalam pengaturan Pasal 15 UUJF.

Pendaftaran perjanjian jaminan pada hakekatnya ditujukan agar pihak ketiga mempunyai kesempatan untuk mengetahui bahwa benda-benda tertentu terikat sebagai jaminan untuk keuntungan kreditor tertentu, untuk suatu jumlah tertentu, dengan janjijanji tertentu. Artinya pendaftaran mempunyai akibat terhadap pihak ketiga di luar perjanjian utang-piutang dengan jaminan.

Melalui pendaftaran perjanjian jaminan, maka pihak ketiga secara tidak langsung menjadi terikat dengan perjanjian utang-piutang dengan jaminan yang ada, dalam bentuk dianggap mengetahui dan diwajibkan untuk menghormati proses utang-piutang yang membebani benda tersebut. Sehingga manakala pihak ketiga melakukan suatu perbuatan hukum terhadap benda tersebut (contohnya membeli), maka pihak ketiga diwajibkan memikul resiko saat benda tersebut sewaktu-waktu akan dilakukan eksekusi atas dasar utang yang telah jatuh tempo.

Demikian artinya pihak ketiga akan dianggap beritikad baik, manakala akan melakukan perbuatan hukum terhadap suatu benda, itu memeriksa terlebih dahulu pada buku pendaftaran atau register di tempat lembaga jaminan yang bersangkutan untuk jenis benda tersebut, guna memastikan apakah benda yang mau dilakukan perbuatan hukum terhadapnya itu tidak sedang dibebani jaminan.

Mendasar pada penjabaran di atas, maka pada jaminan Fidusia, tujuan pendaftaran jaminan adalah agar masyarakat dapat mengakses informasi dan mengetahui keadaan benda yang merupakan obyek jaminan Fidusia. Selain itu, pendaftaran juga bertujuan untuk memberikan kepastiaan terhadap kreditor lainnya mengenai benda yang telah dibebani jaminan Fidusia, sehingga mencegah terjadinya Fidusia ulang sebagaimana yang dilarang oleh Pasal 17 UUJF. Diungkapkan oleh Munir Fuady, maksud dan tujuan sistem pendaftaran jaminan Fidusia itu, adalah: ${ }^{2}$

1. Memberikan kepastian hukum kepada para pihak yang berkepentingan, terutama dengan kreditor yang lain mengenai benda yang telah dibebani dengan jaminan Fidusia;

2. Melahirkan ikatan jaminan Fidusia bagi kreditor penerima jaminan Fidusia;

3. Memberikan hak yang didahulukan (preferen) kepada kreditor penerima Fidusia terhadap kreditor lain, berhubung pemberi Fidusia tetap menguasai benda yang menjadi obyek jaminan Fidusia berdasarkan kepercayaan;

4. Memenuhi asas publisitas.

Satu hal yang perlu diingat, adalah dalam Fidusia, selain perjanjian jaminan nya harus didaftarkan, benda yang dijaminkan pun harus didaftarkan. Kedua hal ini tidaklah sama, sebagaimana diungkapkan oleh Rachmadi Usman yang berpendapat bahwa: Pendaftaran benda tidaklah sama dengan pendaftaran ikatan jaminan. Masing-masing pendaftaran ada aturannya sendiri. Dengan mendaftarkan benda, itu tidak dengan sendirinya benda itu menjadi terikat jaminan. Apabila yang dimaksud dengan pendaftaran itu adalah pendaftaran benda jaminan sekaligus ikatan jaminannya, mestinya benda jaminan didaftarkan atas nama debitor, kemudian dicatat hak kreditor berdasarkan ikatan jaminannya. Dengan itu hak kreditor berdasarkan ikatan jaminan menjadi terdaftar. ${ }^{3}$

Kewajiban pendaftaran ini tetap berlaku meskipun kebendaan yang dibebani dengan jaminan Fidusia berada di luar wilayah Republik Indonesia. Pendaftaran benda yang dibebani dengan jaminan Fidusia dilaksanakan di tempat kedudukan pemberi Fidusia, pendaftarannya mencakup benda, baik yang berada di dalam maupun di luar wilayah Republik Indonesia untuk memenuhi asas publisitas, sekaligus merupakan jaminan kepastian mengenai benda yang telah dibebani dengan jaminan Fidusia.

Disampaikan lebih lanjut oleh Rachmadi Usman, bahwa berdasarkan ketentuan Pasal 11 UUJF, dapat diketahui yang wajib didaftarkan adalah benda yang dibebani dengan jaminan Fidusia. Sementara itu ketentuan dalam Pasal 12 ayat (1), 13 ayat (1),

\footnotetext{
${ }^{2}$ Rachmadi Usman. (2008). Hukum Jaminan Keperdataan. Jakarta: Sinar Grafika, h. 200-201.

3 ibid.
} 
14, dan 16 UUJF menyatakan bahwa yang wajib didaftarkan itu ikatan jaminan Fidusianya. Dengan kata lain berdasarkan beberapa ketentuan tersebut, yang wajib didaftarkan adalah ikatan jaminan Fidusianya beserta janji-janji antara para pihaknya, sekaligus benda yang dijaminkan. Oleh karena itu produk yang diterbitkan oleh kantor pendaftaran Fidusia itu dinamakan dengan sertifikat jaminan Fidusia dan sertifikat benda jaminan Fidusia. ${ }^{4}$

Pendaftaran jaminan Fidusia tidak selalu berjalan lancar, terutama untuk kredit jangka pendek yang mana sesuai pengaturannya Pasal 13 ayat (1) UUJF itu kreditor yang harus mendaftarkan ke kantor pendaftaran Fidusia. Bukan hal yang tidak mungkin akan terjadi keterlambatan pengajuan pendaftaran jaminan Fidusia dikarenakan kesibukan pihak yang berkewajiban mendaftarkan, permasalahan antrian, juga masalah biaya. Berat ringannya biaya itu sedikit banyak bergantung dari besar nilai jaminan. Biaya yang sama untuk nilai jaminan yang kecil, sudah barang tentu akan dirasa lebih berat dari pada jaminan yang nilainya besar. Biaya pendaftaran ini dibebankan pada debitor dan diatur dalam PP Pendaftaran Fidusia.

Beberapa kendala pendaftaran tersebut di atas dapat mengakibatkan kerugian pada pihak kreditor, karena apabila belum didaftarkan, maka sesuai yang telah dibahas sebelumnya, jaminan Fidusia belum lahir dengan sah. Demikian yang menjadi pertimbangan pembuat Undang-Undang dalam memutuskan mekanisme baru pendaftaran jaminan Fidusia, yaitu melalui online. Sebagaimana dalam penjelasan umum PP Pendaftaran Fidusia disampaikan bahwa kantor pendaftaran Fidusia melakukan pendaftaran jaminan Fidusia secara manual yang pada penerapannya memiliki beberapa kendala, antara lain tidak tercapainya pelayanan one-day service mengingat permohonan yang masuk sangat banyak melampaui kemampuan sumber daya manusia dan sarana yang ada. Untuk mengatasi permasalahan tersebut, perlu diciptakan pola pelayanan pendaftaran jaminan Fidusia secara elektronik (online system).

Awal mula pengaturan pendaftaran online ini disampaikan dalam Surat Edaran Ditjen AHU No. AHU-06.OT.03.01 Tahun 2013 tentang Pemberlakuan Sistem Administrasi Pendaftaran Jaminan Fidusia
Secara Elektronik (Online System) yang diterbitkan pada tanggal 5 Maret 2013 oleh Kementerian Hukum dan HAM (Kemenkumham). ${ }^{5}$ Saat ini pengaturannya terletak pada PP Pendaftaran Fidusia.

Semenjak adanya PP Pendaftaran Fidusia, maka aturan lama mengenai pendaftaran manual Fidusia di Kantor Pendaftaran Fidusia di Kantor Wilayah yang tersedia, itu juga ikut terkena imbas sistem pendaftaran online. Artinya pendaftaran Fidusia hanya dapat dilakukan secara online saat ini, baik itu dari orang yang datang ke Kantor Pendaftaran Fidusia dengan membawa berkas bukan digital, nantinya Kantor Pendaftaran Fidusia itu akan mendaftarkannya secara digital. Hal ini sebagaimana ditegaskan dalam Pasal 2 ayat (2) PP Pendaftaran Fidusia yang menegaskan bahwa permohonan pendaftaran diajukan melalui sistem pendaftaran secara elektronik. ${ }^{6}$ Dalam prakteknya hal ini telah diterapkan. Pendaftaran fidusia dapat diakses melalui situs https://fidusia.ahu.go.id/. Pada halaman website tersebut dapat terlihat bahwa untuk mendaftarkan Fidusia saat ini tidak melulu pihak Notaris yang dibebani kewajiban, namun Korporasi, Ritel, dan Kanwil juga dapat mendaftarkannya sendiri melalui situs website tersebut. Hal ini senada dengan pengaturan pada Pasal 2 PP Pendaftaran Fidusia. Satu hal yang pasti adalah tetap adanya kewajiban Notaris yaitu dalam membuat Akta Jaminan Fidusia sebagaimana amanah dari Pasal 5 UUJF. ${ }^{7}$

Keadaan sebagaimana di atas, membawa arti bahwa saat ini semua sertifikat Fidusia yang diterbitkan adalah bertanda tangan digital. Hal ini sebagaimana pengaturan Pasal 7 ayat (2) PP Pendaftaran Fidusia. Keadaan ini sudah mampu memunculkan resiko timbulnya sertifikat Fidusia ganda (palsu) atas suatu benda yang memang

${ }^{5}$ Sundhari. (2018). "Pelaksanaan Pendaftaran Jaminan Fidusia Secara Elektronik (Online)”. Jurnal Morality. Volume 4 Nomor 2 Desember 2018. Palangkaraya: Universitas PGRI Palangkaraya, h. 161.

${ }^{6}$ Nizar Apriansyah. (2018). "Keabsahan Sertifikat Jaminan Fidusia yang Didaftarkan Secara Elektronik". Jurnal Ilmiah Kebijakan Hukum. Volume 12 Nomor 3 November 2018. Jakarta: Badan Penelitian dan Pengembangan Hukum dan HAM, Kementerian Hukum dan HAM RI, h. 230.

${ }^{7}$ Kashadi. (2016). "Pelaksanaan Pendaftaran Jaminan Fidusia Melalui Online Oleh Kreditor Penerima Fidusia (Studi Kasus di Bank Perkreditan Rakyat Kota Semarang)". Diponegoro Law Journal. Volume 5 Nomor 3 Tahun 2016. Semarang: Universitas Diponegoro, h. 8. 
benar-benar dijadikan objek jaminan Fidusia, untuk disalahgunakan oleh pihak yang tidak berhak. Resiko sebagaimana di atas ini semakin besar kemungkinannya terjadi, saat pengecekan status Fidusia dipermudah pula melalui sistem online.

Pencarian Fidusia dapat dilakukan melalui situs https://ahu.go.id/pencarian/fidusia, situs ini mampu memberikan informasi mengenai jaminan Fidusia, hanya dengan menginput:

1. Nomor sertifikat Fidusia; atau

2. Obyek berserial nomor (seperti mesin, kendaraan roda dua, roda empat, dan lain sebagainya); atau

3. Obyek tidak berserial nomor (seperti hak paten, hak cipta, hewan ternak, dan lain sebagainya); atau

4. Identitas Pemberi Fidusia (Nama, NPWP, NIK). Manakala informasi mengenai jaminan Fidusia dapat diberikan kepada khalayak bebas tanpa didahului kewajiban pemberian atau penunjukan identitas si pencari informasi, maka maka sudah barang tentu dapat disalahgunakan oleh pihak pencari informasi yang mempunyai itikad buruk. Baik itu dalam bentuk peretasan server penyimpanan data jaminan Fidusia, ataupun dalam bentuk pemalsuan sertifkat jaminan Fidusia. Mengingat praktek model eksekusi obyek jaminan Fidusia hingga saat ini pun masih belum semuanya sesuai norma yang berlaku dalam UUJF. Beberapakali masih sering dilakukan eksekusi obyek jaminan Fidusia dengan cara meminta jasa bantuan kepada pihak yang dianggap mampu dan berwenang dalam melakukan pencarian dan penyitaan obyek jaminan Fidusia, cara ini dinilai lebih cepat walaupun memerlukan biaya tambahan (untuk jasa bantuan tersebut) yang tidaklah murah. Menurut hemat penulis dalam hal ini adalah pemerintah sudah selayaknya membatasi keterbukaan informasi data jaminan Fidusia secara online, artinya informasi setidaknya hanya memberikan keterangan benar atau tidaknya telah terjadi jaminan Fidusia, manakala seseorang ingin mengetahui dengan detail, maka seseorang diwajibkan mendatangi Kantor Pendaftaran Fidusia terdekat, dan meminta detail informasi dengan terlebih dahulu menunjukkan identitas.

Pendaftaran Fidusia secara online, dengan mekanisme yang ada pada PP Pendaftaran Fidusia, belum mengatur mekanisme pendaftaran atas benda yang akan dijadikan jaminan Fidusia, sebagaimana diatur dalam Pasal 11 UUJF. Amanah UUJF, beserta Penjelasan Pasal 11 UUJF dengan jelas menegaskan yang pada intinya adalah pendaftaran benda yang akan dijadikan obyek jaminan Fidusia, dilaksanakan di Kantor Pendaftaran Fidusia, yang artinya bersamaan dengan pendaftaran jaminan Fidusia. Hal ini juga mengingat apa yang disampaikan oleh Rachmadi Usman bahwa itu produk yang diterbitkan oleh kantor pendaftaran Fidusia itu dinamakan dengan sertifikat jaminan Fidusia dan sertifikat benda jaminan Fidusia. ${ }^{8}$

Terkait benda yang menjadi obyek jaminan Fidusia, pada Pasal 6 UUJF dan Pasal 3 PP Pendaftaran Fidusia telah ditegaskan bahwa akta jaminan Fidusia memuat:

1. Identitas pihak pemberi dan penerima Fidusia;

2. Data perjanjian pokok yang dijamin Fidusia;

3. Uraian mengenai benda yang menjadi obyek jaminan Fidusia;

4. Nilai penjaminan; dan

5. Nilai benda yang menjadi obyek jaminan Fidusia. Pada akta jaminan Fidusia yang ada, bahkan yang dikeluarkan pada awal tahun 2018 pun masih belum dapat memenuhi poin nomor 3 (tiga) di atas, karena di sertifikat jaminan Fidusia hanya dituliskan "Obyek Jaminan Fidusia sesuai yang tertuang dalam Akta nomor XX, tanggal XXXXXXXX yang dibuat Notaris $X X X X$ berkedudukan di $X X X X X$ ". Dapat dipahami bahawa hakekat dari diaturnya poin nomor 3 (tiga) di atas adalah guna memenuhi asas spesialitas dalam Hukum Jaminan, maka setidaknya dalam sertifikat itu disebutkan secara tertulis spesifikasi detail dari obyek yang dijaminkan. Demikian uraian mengenai obyek jaminan Fidusia itu menjadi satu kesatuan tertulis dalam Sertifikat Jaminan Fidusia, bukan hanya dianggap sebaagai satu kesatuan dengan cara ditulis dalam dokumen yang lain (tidak hanya ditulis dalam Akta Jaminan Fidusia oleh Notaris). Menurut hemat penulis, mengenai benda yang dijadikan obyek jaminan Fidusia ini, haruslah dibuat mekanisme baru dalam keseluruhan mekanisme pendaftaran online jaminan Fidusia, yaitu adanya mekanisme pendaftaran benda jaminan, manakala benda itu belum didaftarkan (hal ini guna memenuhi amanah Pasal 11 UUJF). Selain itu dalam Sertifikat Jaminan Fidusia, harus ditulis secara detail spesifikasi dan ciri dari obyek yang dijadikan jaminan Fidusia guna

8 ibid. 
memenuhi asas spesialitas dalam Sertifikat Jaminan Fidusia tersebut.

Selanjutnya, melalui penggunaan pendaftaran dengan metode online, dokumen yang dicetak oleh kreditor (penerima Fidusia) adalah sertifikat jaminan Fidusia, sertifkat tersebut tidak ada tulisan "salinan" atau "grosse", sehingga dapat dipahami bahwa yang didapatkan oleh kreditor adalah minuta (asli-nya), sedangkan dalam Pasal 14 ayat (3) UUJF ditegaskan bahwa sertifikat Jaminan Fidusia merupakan salinan Buku Daftar Fidusia, sehingga artinya semestinya Kantor Pendaftaran Fidusia itu tidak hanya menyimpan bentuk softcopy dari sertifikat jaminan Fidusia yang tersimpan di server Pendaftaran Fidusia, namun juga menyimpan cetak hardcopy sertifikat Jaminan Fidusia di Kantor Pendaftaran Fidusia, manakala tidak demikian, maka Pasal 14 ayat (3) UUJF tidak dapat dipenuhi. Manakala Kantor Pendaftaran Fidusia juga memiliki hardcopynya, maka antara Sertifikat yang dimiliki oleh Kantor Pendaftaran Fidusia sebagai arsip dan Salinan Buku Daftar Fidusia, haruslah berbeda dan tidak boleh identik sama dengan yang dimiliki oleh kreditor. Aslinya hanya boleh satu, sedangkan lain lagi adalah Salinannya. Oleh karenanya menurut hemat penulis, yang benar adalah sertifikat asli jaminan Fidusia itu tidak ada irah-irahnya, dan disimpan oleh kantor pendaftaran Fidusia, sedangkan yang diberikan kepada kreditor adalah salinan atau "grosse"nya dengan tambahan irah-irah, sehingga nantinya jelas dan pasti mengenai eksekusinya, irahirahnya hanya ada pada satu dokumen saja, tidak pada dua dokumen, artinya untuk pelaksanaan eksekusi melalui titel eksekutorial, nanti mendasarkan pada salinan atau "grosse" sertifikat jaminan Fidusia yang dimiliki oleh kreditor.

Berkenaan dengan irah-irah yang tertulis dalam Sertifikat Jaminan Fidusia, dengan adanya pendaftaran Fidusia secara online ini, kewenangan pemberian irah-irah semakin meluas. Manakala diukur secara historis, awal mula kewenangan pemberian irah-irah tersebut hanya dimiliki oleh Hakim yang akan dituangkan dalam Putusannya. Dimana Putusan yang inkracht (mempunyai kekuatan hukum tetap) dan memuat irah-irah, akan mempunyai kekuatan untuk dilakukan eksekusi (kekuatan eksekutorial). Pada perkembangannya, terdapat beberapa dokumen yang memerlukan irah-irah, yaitu dalam hal utang-piutang, yang mana tujuan pemberian irah-irah itu sebagai salah satu bentuk perlindungan hukum terhadap pihak kreditornya, dengan tujuan penyelesaian sengketanya tidak perlu dengan proses yang panjang dan berbelit-belit, dengan kata lain dokumen yang dimilikinya itu dapat dilaksanakan eksekusi (atas perintah Pengadilan) tanpa adanya proses persidangan. Dokumen yang dimaksud adalah akta pengakuan utang yang amanahnya ditegaskan melalui Pasal 224 Herzeine Indonesisch Reglement. Sedangkan untuk pembuatan akta pengakuan utang, sudah barang tentu harus ada perjanjian utangpiutang sebelumnya. Perjanjian utang-piutang baik itu tertulis atau tidak, sudah barang tentu dapat dibuat dengan isi yang bebas dan kompleks sebagaimana asas kebebasan berkontrak dalam Pasal 1338 BW. Hakim dengan segala kewajiban memutuskan perkara-perkara hukum yang ada dan menumpuk, sudah barang tentu akan terbatas dalam menjangkau segala aspek perihal perjanjian utang-piutang yang akan dibuatkan akta pengakuan utang. Disamping itu, terdapat seseorang yang atas keilmuannya dianggap sangat berkompeten dalam bidang perjanjian utangpiutang yang demikian, orang tersebut adalah Notaris. Oleh karenanya, kewenangan pemberian irah-irah mulai terbagi tidak hanya oleh Hakim, namun juga dapat dilakukan oleh Notaris dalam hal pembuatan akta pengakuan utang.

Selain pada Putusan Hakim yang inkracht, dan akta pengakuan utang, pemberian irah-irah juga dilakukan pada dokumen Grosse Akta Hipotek sesuai Pasal 224 HIR. Grosse Akta Hipotek adalah Salinan akta Hipotek yang diterbitkan atas adanya utang-piutang dengan menggunakan lembaga jaminan Hipotek. Akta Hipotek dan Grosse Akta Hipotek dibuat oleh pejabat yang ditunjuk oleh undang-undang. Demikian artinya berkembang lagi kewenangan pemberian irah-irah, selain oleh Hakim, Notaris dalam hal pembuatan akta pengakuan utang, juga oleh pejabat yang ditunjuk undang-undang untuk membuat Grosse Akta Hipotek.

Pada perkembangannya pemberian irah-irah dengan tujuan mempermudah proses penyelesaian sengketa tanpa perlu menunggu waktu yang lama dan tanpa perlu menjalani proses sidang demi sidang, dilakukan juga untuk lembaga jaminan utangpiutang selain Hipotek, perkembangan ini dimulai dari adanya lembaga jaminan Hak Tanggungan dan 
Fidusia. Irah-irah juga dituliskan pada Sertifikat Hak Tanggungan dan Sertifikat Jaminan Fidusia. Kewenangan pemberian irah-irah ini pun mengikuti aturan dalam Hipotek, yaitu kewenangannya dimiliki oleh pejabat yang ditunjuk oleh undang-undang.

Pada prakteknya hingga saat ini, baik itu Grosse Akta Hipotek, Sertifikat Hak Tanggungan, dan Sertifikat Jaminan Fidusia, yang mana memuat irah-irah tersebut, ternyata dalam hal substantif dokumen yang dikuatkan oleh irah-irah itu dapat dinilai tidak mampu memberikan perlindungan hukum yang baik bagi kreditornya. Semua dokumen tersebut mengandalkan akta yang dibuat oleh Notaris sebelum dilakukan pendaftaran jaminan, dan akta Notaris tersebut dianggap sebagai satu kesatuan dengan sertifikat dan grosse akta tersebut. Hal ini menandakan bahwa penunjukan pejabat oleh undangundang untuk pemberian kewenangan meletakkan irah-irah pada Grosse Akta Hipotek, Sertifikat Jaminan Fidusia dan Sertifikat Hak Tanggungan, ini tidak sesuai sasaran yang diharapkan oleh pembuat undang-undang itu sendiri. Pada masa mendatang, hampir dapat dipastikan irah-irah Demi Keadilan Berdasarkan Ketuhanan Yang Maha Esa ini tidak mempunyai arti penting lagi, hanya sekedar memberi arti dapat dieksekusi dengan mudah, namun substansi dokumennya sendiri tidaklah mencerminkan dokumen hukum yang layak untuk dijadikan dokumen utama dalam pelaksanaan eksekusi obyek jaminan. Menurut hemat penulis, pemberian irahirah ini, manakala tidak mampu mencari pihak yang sebenar-benarnya karena keilmuannya itu pantas diberikan kewenangan dalam pemberian irah-irah, maka substansi yang komprehensif itu diperlukan dalam dokumen yang terkait, pada jaminan Fidusia, substansi yang komprehensif dituntut ada dalam Sertifikat Jaminan Fidusia, demikian perubahan substansi Sertifikat Jaminan Fidusia yang ada saat ini, dapat dilakukan dengan menambahkan dan merubah beberapa hal sebagaimana telah dijabarkan di atas.

\section{PENUTUP}

\section{Kesimpulan}

Pendaftaran jaminan Fidusia secara online merupakan terobosan yang luar biasa oleh pemerintah dalam memfasilitasi rakyatnya yang butuh efektifitas dalam dunia bisnis khususnya dalam hal perkreditan yang disertai jaminan Fidusia. Namun aturan dan penerapan yang ada, khususnya dalam sertifikatnya, ternyata tidak mampu memberikan perwujudan yang maksimal akan asas publisitas dan spesialitas yang justru berguna sebagai payung kepastian dan perlindungan hukum pihak kreditor. Akibatnya perlindungan kreditor tidak maksimal. Karakter perlindungan hukum kreditor dalam pendaftaran Fidusia secara biasa dan online adalah berbeda. Pembaharuan UUJF diperlukan dengan beberapa pertimbangan antara lain yaitu pembatasan keterbukaan informasi data jaminan Fidusia secara online, adanya mekanisme pendaftaran benda jaminan, harus ditulis secara detail spesifikasi dan ciri dari obyek yang dijadikan jaminan Fidusia guna memenuhi asas spesialitas dalam Sertifikat Jaminan Fidusia tersebut, sertifikat asli jaminan Fidusia itu tidak ada irah-irahnya, dan disimpan oleh kantor pendaftaran Fidusia, sedangkan yang diberikan kepada kreditor adalah salinannya, juga manakala tidak mampu mencari pihak yang sebenar-benarnya karena keilmuannya itu pantas diberikan kewenangan dalam pemberian irah-irah, maka substansi yang komprehensif itu diperlukan dalam Sertifikat Jaminan Fidusia.

\section{Rekomendasi}

Aturan mengenai jaminan Fidusia saat ini terdapat banyak kelemahan dan kejelasan, disamping itu letak aturannya juga tersebar. Diharapkan pemerintah lebih memperhatikan lembaga jaminan Fidusia yang sangat diminati di Indonesia ini, dengan cara menciptakan satu unifikasi aturan hukum Jaminan Fidusia, sekaligus melakukan pembaharuan UUJF. Sehingga aturan jaminan Fidusia tidak tersebar, juga dapat lebih memberikan perlindungan dan kepastian hukum bagi para pihak, terutama kreditor.

\section{DAFTAR PUSTAKA}

\section{Peraturan Perundang-undangan:}

Burgerlijk Wetboek.

Herzien Inlandsch Reglement (HIR).

Undang-Undang Nomor 42 Tahun 1999 tentang Jaminan Fidusia.

Peraturan Presiden Republik Indonesia Nomor 9

Tahun 2009 tentang Lembaga Pembiayaan. 
Peraturan Pemerintah Nomor 21 Tahun 2015 tentang

Tata Cara Pendaftaran Jaminan Fidusia dan Biaya Pembuatan Akta Jaminan Fidusia.

Keputusan Menteri Keuangan Republik Indonesia Nomor 1251/KMK.013/1988 tentang Ketentuan dan Tata Cara Pelaksanaan Lembaga Pembiayaan.

Surat Edaran Ditjen AHU No. AHU-06.OT.03.01

Tahun 2013 tentang Pemberlakuan Sistem Administrasi Pendaftaran Jaminan Fidusia Secara Elektronik (Online System).

Peraturan Otoritas Jasa Keuangan Nomor 29/

POJK.05/2014 tentang Penyelenggaraan Usaha Perusahaan Pembiayaan.

\section{Buku:}

Munir Fuady. (2000). Hukum Jaminan Utang. Jakarta: Erlangga.

Rachmadi Usman. (2008). Hukum Jaminan Keperdataan. Jakarta: Sinar Grafika.

\section{Jurnal:}

Kashadi. (2016). "Pelaksanaan Pendaftaran Jaminan Fidusia Melalui Online Oleh Kreditor Penerima Fidusia (Studi Kasus di Bank Perkreditan Rakyat Kota Semarang)". Diponegoro Law Journal. Volume 5 Nomor 3 Tahun 2016. Semarang: Universitas Diponegoro.

Nizar Apriansyah. (2018). "Keabsahan Sertifikat Jaminan Fidusia yang Didaftarkan Secara Elektronik". Jurnal Ilmiah Kebijakan Hukum. Volume 12 Nomor 3 November 2018. Jakarta: Badan Penelitian dan Pengembangan Hukum dan HAM, Kementerian Hukum dan HAM RI.

Sundhari. (2018). "Pelaksanaan Pendaftaran Jaminan Fidusia Secara Elektronik (Online)". Jurnal Morality. Volume 4 Nomor 2 Desember 2018. Palangkaraya: Universitas PGRI Palangkaraya.

\section{Website:}

https://fidusia.ahu.go.id/ diakses tanggal 7 Januari 2019 pukul 15.43 WIB.

https://ahu.go.id/pencarian/fidusia diakses tanggal

7 Januari 2019 pukul 16.09 WIB. 